\title{
MicroRNA Function and Mechanism: Insights from Zebra Fish
}

\author{
A.F. Schier AND A.J. GiRALDEZ \\ Department of Molecular and Cellular Biology, Harvard University, Cambridge, Massachusetts 02138
}

\begin{abstract}
MicroRNAs (miRNAs) are small RNAs that bind to the 3'UTR of mRNAs. We are using zebra fish as a model system to study the developmental roles of miRNAs and to determine the mechanisms by which miRNAs regulate target mRNAs. We generated zebra fish embryos that lack the miRNA-processing enzyme Dicer. Mutant embryos are devoid of mature miRNAs and have morphogenesis defects, but differentiate multiple cell types. Injection of miR-430 miRNAs, a miRNA family expressed at the onset of zygotic transcription, rescues the early morphogenesis defects in dicer mutants. miR-430 accelerates the decay of hundreds of maternal mRNAs and induces the deadenylation of target mRNAs. These studies suggest that miRNAs are not obligatory components of all fate specification or signaling pathways but facilitate developmental transitions and induce the deadenylation and decay of hundreds of target mRNAs.
\end{abstract}

miRNAs are approximately 22-nucleotide small RNAs that act as posttranscriptional repressors by binding to the 3'UTR of target mRNAs (Lee et al. 1993; Reinhart et al. 2000; Bartel 2004; Kloosterman and Plasterk 2006). In animals, mature miRNAs are generated from a primary transcript (pri-miRNA) through sequential cleavage by nucleases belonging to the RNAse III family. Initially, Drosha cleaves the pri-miRNA and excises a stem-loop precursor (pre-miRNA), which is then cleaved by Dicer into an RNA duplex (Bernstein et al. 2001; Grishok et al. 2001; Hutvagner et al. 2001; Ketting et al. 2001; Knight and Bass 2001). One strand of the duplex constitutes the mature miRNA, which is incorporated into a silencing complex (RISC) and guides it to target mRNAs (Hammond et al. 2000; Hutvagner and Zamore 2002; Khvorova et al. 2003; Schwarz et al. 2003). The 5' region of the miRNA (seed) is the main determinant of target recognition (Lai 2002; Lewis et al. 2003, 2005; Doench and Sharp 2004; Brennecke et al. 2005). Hundreds of miRNAs have been identified and thousands of targets have been predicted (Lagos-Quintana et al. 2001; Lau et al. 2001; Lee and Ambros 2001; Enright et al. 2003; Stark et al. 2003, 2005; Ambros 2004; Bartel 2004; Rehmsmeier et al. 2004; Berezikov et al. 2005; Farh et al. 2005; Krek et al. 2005; Lai 2005; Lewis et al. 2005; Miranda et al. 2006; Rajewsky 2006; Sood et al. 2006). However, the developmental roles of microRNAs are largely elusive (Alvarez-Garcia and Miska 2005; Kloosterman and Plasterk 2006), and it is still controversial how target mRNAs are repressed (Pillai 2005; Valencia-Sanchez et al. 2006). We have used the zebra fish embryo as a model system to investigate these issues.

\section{ZEBRA FISH EMBRYOS THAT LACK MATURE MIRNAS UNDERGO ABNORMAL MORPHOGENESIS}

The global function of miRNAs has been unclear, and it is controversial whether miRNAs act as switches or modulators of biological processes (Bartel and Chen 2004). We therefore wished to create embryos that lack all mature miRNAs (Fig. 1B). To this end, we used genetic and embryological manipulations to generate embryos that lacked all Dicer activity (Fig. 1B; Fig. 2) (Ciruna et al. 2002; Giraldez et al. 2005). Several lines of evidence indicated that these maternal-zygotic dicer mutants (MZdicer) lacked mature miRNAs. For example, northern analyses detected only pre-miRNAs, and reporter genes that contain miRNA target sites in their $3^{\prime}$ UTRs were repressed in wild type but not in MZdicer mutants (Giraldez et al. 2005).

MZdicer mutant embryos had severe morphogenesis defects, including abnormal gastrulation movements, impaired brain ventricle formation, and somite defects, and died on day 5 of development (Giraldez et al. 2005). Interestingly, however, different cell fates were specified, including hematopoietic, muscle, and neuronal cell types (Fig. 3B). Dorsal-ventral and anterior-posterior patterning were normal, and the major signaling pathways active in the early embryo were not grossly misregulated, including signaling by Nodal, BMP, Wnt, FGF, Hedgehog, and Retinoic Acid. Most strikingly, germ cells devoid of Dicer activity developed, renewed, and generated oocytes and sperm without apparent defects. These results indicate that mature miRNAs are not obligatory regulators of cell-fate

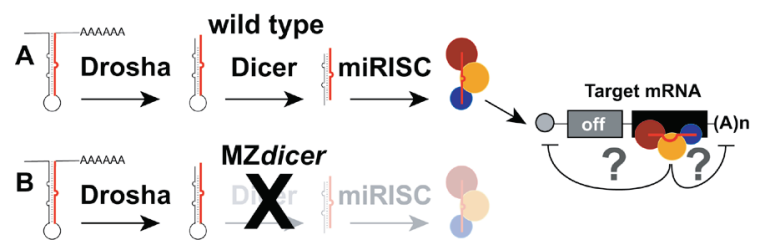

Figure 1. Maternal-zygotic dicer mutants do not process miRNAs. $(A)$ Drosha cleaves the pri-miRNA and excises a stemloop precursor. Dicer cleaves the hairpin to give rise to a miRNA:miRNA* duplex. One strand of this duplex is incorporated in a protein complex to form a miRNA-induced silencing complex (miRISC). The miRNA serves as a guide for this complex to the target mRNA. This leads to translational repression and accelerated mRNA degradation. (B) MZdicer mutants lack the miRNA processing enzyme Dicer and lack mature miRNAs. 


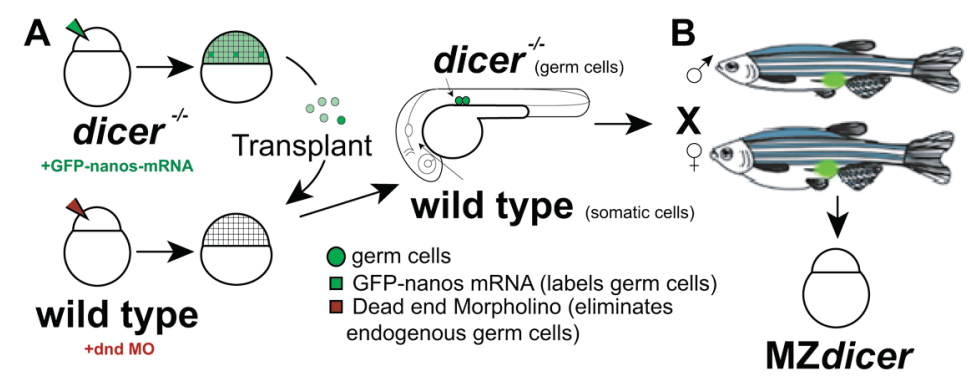

Figure 2. Germ-line replacement technique to generate MZdicer mutants. (A) Schematic representation of the germ-line replacement technique used to generate maternal-zygotic dicer mutants. Depletion of host germ cells was accomplished by injection of a morpholino (Dead end morpholino; dnd MO) that blocks primordial germ cell development in host embryos, resulting in sterility. Donor germ cells labeled with GFP-nos-3'UTR were transplanted into these hosts during early embryogenesis (Ciruna et al. 2002). (B) Hosts containing dicer/dicer germ cells were raised to adulthood. These fish only harbored dicer/dicer PGCs. Intercrossing resulted in embryos that lacked both maternal and zygotic Dicer RNase III activity (MZdicer). Additional fertile adults were generated using MZdicer embryos as germ cell donors. These germ cells gave rise to mature and functional eggs and sperm, which generated embryos with a MZdicer phenotype.

specification, differentiation, and signaling during early embryonic development in zebra fish. Instead, miRNA function appears to be required for the repression of mRNAs whose misexpression interferes with morphogenetic processes (Fig. 3B) (Giraldez et al. 2005).

\section{THE MIR-430 FAMILY REGULATES MORPHOGENESIS}

In vitro generated miRNA duplexes were active upon injection into MZdicer mutants (Fig. 3A), suggesting that Dicer is not required for the effector steps of miRNA function (Giraldez et al. 2005). Using this injection assay, we found that members of the miR-430 family rescued the early morphogenesis defects of MZdicer mutants but were not able to suppress later phenotypes (Fig. 3B-D and Fig. 4) (Giraldez et al. 2005). miR-430 expression begins after the 500-cell stage, when the zygotic genome initiates transcription. Members of the miR-430 family are the major class of miRNAs during early embryogenesis and are expressed ubiquitously throughout embryonic development in zebra fish and Xenopus. After mid-embryogenesis, many other miRNAs initiate their expression (Fig. 4A) (Chen et al. 2005; Giraldez et al. 2005; Watanabe et al. 2005). Their lack likely accounts for the later defects and lethality of miR-430-injected MZdicer mutants. These results suggest that miR-430 regulates mRNAs whose overexpression affects morphogenesis.

\section{MIR-430 HAS HUNDREDS OF TARGET MRNAS}

Reporter mRNAs with miR-430 target sites were efficiently degraded in wild type but not in MZdicer mutants (Giraldez et al. 2006). These results led us to hypothesize that in vivo targets might also accumulate in the absence of miR-430 (Fig. 5A). We therefore performed expression profiling on wild-type embryos, MZdicer mutants, and MZdicer mutants injected with miR-430, leading to the identification of more than 700 mRNAs that accumulated in the absence of miR-430 (Giraldez et al. 2006). Strikingly, two-thirds of these
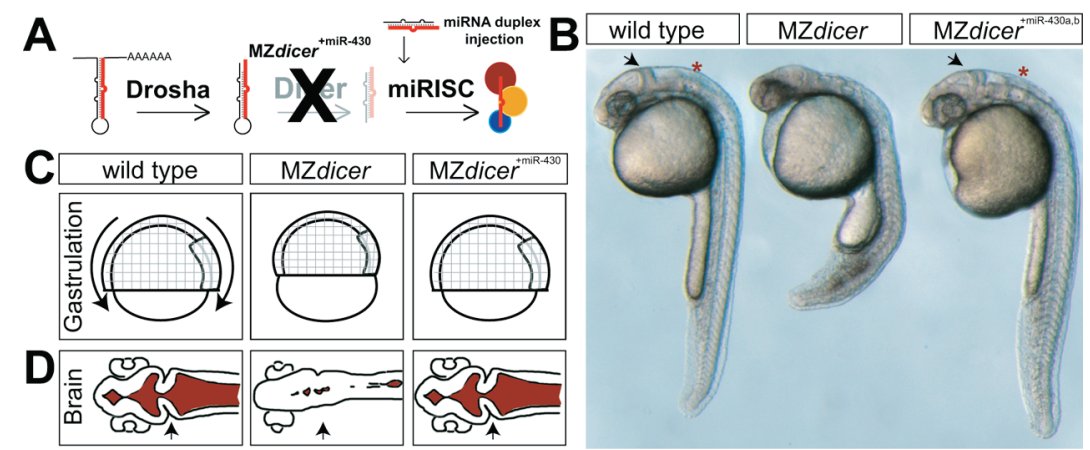

Figure 3. Abnormal morphogenesis in MZdicer mutants. $(A)$ Schematic representation showing that MZdicer mutants lack mature miRNAs but injected processed miRNA duplexes reconstitute active miRISC. (B) Wild type (left), MZdicer mutants (center) display morphogenesis defects in the retina, brain, trunk, and tail. MZdicer injected at the one-cell stage with miR-430a+b duplex (right). Note the rescue of brain morphogenesis (asterisk), the midbrain-hindbrain boundary (arrow), and the trunk morphology. (C) Schematic representation shows the gastrulation defects in MZdicer mutants with a slower epiboly compared to wild type. $(D)$ Schematic representation shows a dorsal view of a 30-hr zebra fish brain in wild type, MZdicer, and rescued embryos. The brain ventricles are labeled in red, and the arrow indicates the mid-hindbrain boundary. 


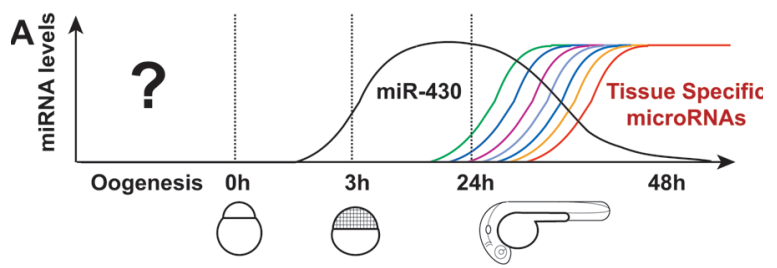

B dre-miR-430a $\quad 5^{\prime}$ - UAAGUGCU-AUUU - GUUGGGGUAG - 3' dre-miR-430b dre-miR-430c - UAAGUGCUUCUCU - -UUGGGGUAG. xla-miR-427 hsa-miR-302a hsa-miR-372 hsa-miR-520d

hsa-miR-93 hsa-miR-20 hsa-miR-17 hsa-miR-106a AAAGUGCUUUCU -GUUUUGGGCG - AAAGUGCUUCCAU - GUUUUGGUGA - AAAGUGCUGC GACA - UUUGAGCGU AAAGUGCUUCUCUUUGGU -GGUU - AAAGUGCU-GUUC - GUGCAGGUAG UAAAGUGCUUAU - - AGU GCAGGUACAAAGUGCUUAC - - AGUGCAGGUAGU

Figure 4. The miR-430 family of miRNAs. (A) Schematic representation showing the expression of miR-430 compared to other miRNAs in zebra fish embryos. MiR-430 starts to be expressed at the onset of zygotic transcription, is the predominant miRNA expressed during the first 18 hours of development, and decays by 48 hours postfertilization. Other miRNAs start to be expressed in a tissue-specific manner after $\sim 18$ hours postfertilization (Wienholds et al. 2005). It is currently unknown which miRNAs, if any, are expressed during oogenesis or before zygotic transcription. $(B)$ Alignment of the zebra fish miR-430 family of miRNAs (Danio rerio, dre) with the Xenopus laevis miR-427 (Watanabe et al. 2005) and human miRNAs. miR-520 is a human miRNA belonging to a large miRNA cluster expressed in the placenta (Bentwich et al. 2005). miR-372 is a stem-cell miRNA that can cause germ cell tumors (Voorhoeve et al. 2006). The miR-17-20 family of miRNAs has been identified as a potential human oncogene (Ota et al. 2004; He et al. 2005).
mRNAs had 3'UTR sequences that were complementary to the miR-430 seed. Large-scale target validation using in vivo reporter assays revealed that the majority of putative targets was regulated by miR-430 in vivo (Fig. 5B). We estimate that miR-430 regulates at least 300 mRNAs. This number is likely an underestimate. First, the microarray contained only about $50 \%$ of all zebra fish genes. Second, expression profiling would not identify targets that are regulated only at the translational level. Hence, it is conceivable that miR-430 directly regulates more than 1000 different mRNAs (Giraldez et al. 2006).

\section{MIR-430 ACCELERATES THE CLEARANCE OF MATERNAL MRNAS}

Strikingly, the large majority of miR-430 targets was maternally expressed and accumulated in the absence of miR-430 (Giraldez et al. 2006). Conversely, we found that $40 \%$ of maternal mRNAs had predicted miR-430 sites. These observations suggest that miR-430 is a key regulator of maternal mRNAs and accelerates their decay (Fig. 6). The aberrant accumulation of maternal mRNAs and their prolonged translation is therefore the likely cause of the morphogenesis defects observed in the absence of miR-430.

These results establish miR-430 as a key regulator of the maternal-to-zygotic transition. This is a universal transition in animal development when the embryo initiates the transcription of its genome (zygotic phase). The preceding stage of development is driven by maternally deposited mRNAs, and the genome is silent (maternal phase). The maternal-to-zygotic transition is still poorly understood, but it coincides with the patterning of the embryo and the

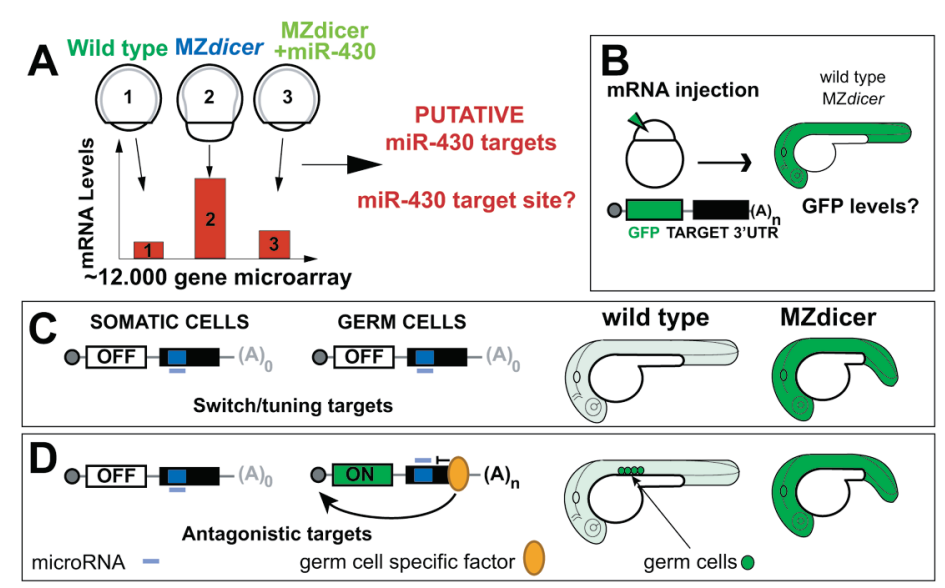

Figure 5. Regulation of miR-430 targets. (A) Schematic representation showing the strategy used to identify miR-430 targets in vivo using microarray analysis. Comparison of mRNA expression levels between MZdicer mutants and [MZdicer ${ }^{+ \text {miR-430 }}$ and wild type]. Putative targets must fulfill two criteria: (1) the mRNA must be up-regulated more than 1.5-fold in MZdicer compared to wild type and MZdicer ${ }^{+m i R-430} ;(2)$ it must contain a 6-mer sequence in the $3^{\prime}$ UTR complementary to miR-430 seed. $(B)$ A fraction of the putative targets were tested using injection of a GFP reporter mRNA with the $3^{\prime}$ UTR of the target mRNA that is wild type or mutant for the miR-430 target sites. The levels of GFP expression in wild-type and MZdicer embryos were compared at 25-30 hours postfertilization. $(C)$ Schematic representation showing that a target is validated when the GFP expression is repressed in wild-type but not in MZdicer embryos. In case of direct regulation, mutations in the miR-430 target site abolish repression in wild type. $(D)$ Schematic representation showing that some targets are regulated by miR-430 in somatic cells but not germ cells despite the presence of miR-430 in both cell types. Model showing that a germ-cell-specific factor (orange) binds to the 3'UTR of antagonistic targets to inhibit miRNA function or enhance translation resulting in germ-cell-specific expression of the reporter mRNA. 


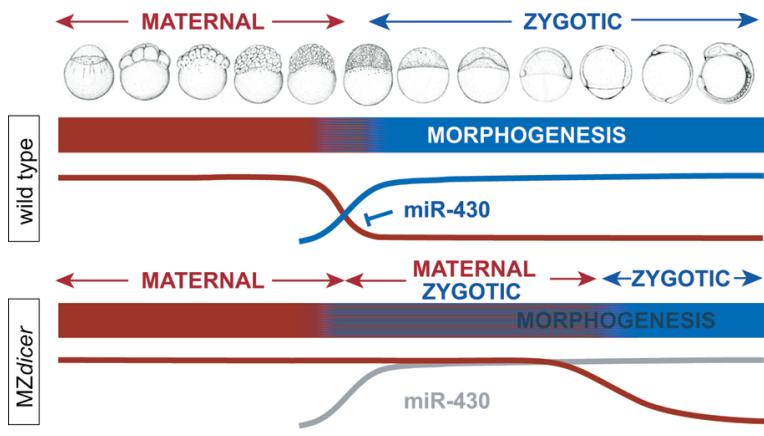

Figure 6. miR-430 accelerates the clearance of maternal mRNAs. Role of miR-430 in maternal-to-zygotic transition. In the presence of miR-430 (blue), a large set of maternal mRNAs (red) is posttranscriptionally regulated, allowing normal morphogenesis during zygotic stages. In the absence of miR-430 (gray), maternal mRNAs and their products accumulate and interfere with morphogenesis. (Reprinted, with permission, from Giraldez et al. 2006 [C AAAS].)

degradation of maternal mRNAs (Newport and Kirschner 1982a,b; Richter et al. 1990; Kane and Kimmel 1993; Richter 1999; Pelegri 2003; de Moor et al. 2005). Our results suggest that miR-430 transcription initiates at the maternal-to-zygotic transition to accelerate the degradation and repression of a large fraction of maternal mRNAs.

\section{TWO CLASSES OF MIR-430 TARGETS}

Reporter assays using the 3'UTR of putative miR-430 target mRNAs revealed that the large majority of targets were uniformly repressed in all embryonic cells; i.e., in germ cells and all somatic cells (Fig. 5C). This observation is consistent with the ubiquitous expression of miR430. Strikingly, however, at least two genes, nanos and tudor-like, were more susceptible to miR-430 repression in somatic cells than in germ cells (Fig. 5D) (Mishima et al. 2006). Zebra fish germ cells are set aside during blastula stages and accumulate specific mRNAs and proteins (Yoon et al. 1997; Knaut et al. 2000; Koprunner et al. 2001; Raz 2004). We found that the 3'UTRs of nanos and tudor-like were repressed in somatic cells in the presence, but not in the absence, of miR-430. In contrast, expression in germ cells was maintained even when miR-430 was present (Fig. 5D). These results suggest that some 3'UTRs can be effective miRNA targets in one cell type but not another. Such 3'UTRs might contain activating or derepressing elements that counteract the effects of the miRNA, resulting in differential, tissue-specific regulation (Fig. 4D) (Mishima et al. 2006).

\section{MIRNAS INDUCE DEADENYLATION AND DECAY OF TARGET MRNAS}

Previous studies had shown that miRNAs block the translation of target mRNAs and, in some cases, induced mRNA decay (Lee et al. 1993; Olsen and Ambros 1999; Reinhart et al. 2000; Bagga et al. 2005; Lim et al. 2005; Pillai 2005; Pillai et al. 2005). Since mRNA translation and stability depend on the poly(A) tail (Gallie 1991; de Moor et al. 2005), we tested the polyadenylation status of miR-430 targets (Fig. 7). We found that miR-430 induced the rapid deadenylation of target mRNAs (Giraldez et al. 2006; Mishima et al. 2006). Deadenylation was not an indirect effect of translational repression, because nontranslatable targets were efficiently deadenylated in the presence, but not the absence, of miR-430 (Giraldez et al. 2006; Mishima et al. 2006). Many maternal mRNAs are deadenylated in the egg and polyadenylated upon fertilization (Slater et al. 1972; Slater et al. 1973; Wilt 1973; McGrew et al. 1989; Richter 1999; de Moor et al. 2005).

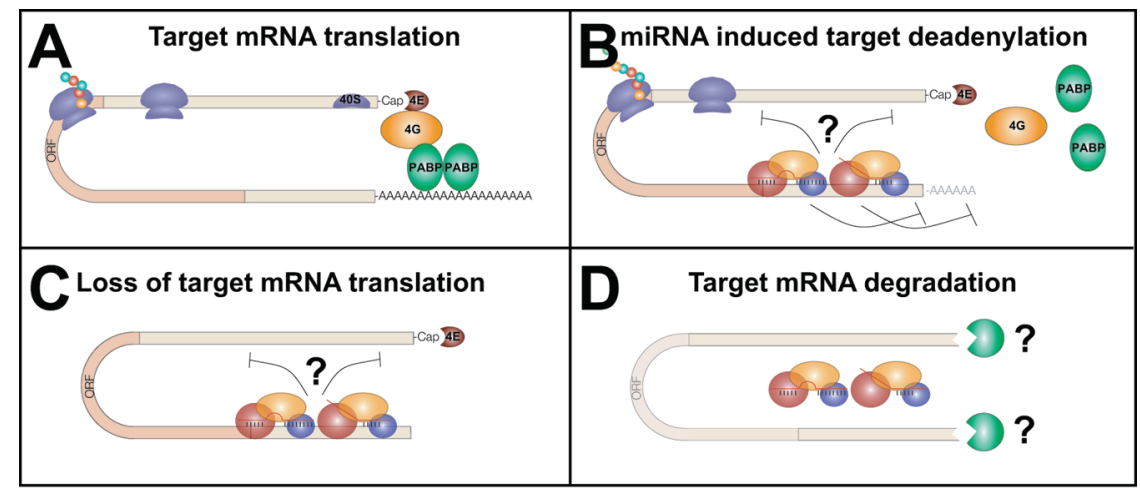

Figure 7. Model for the posttranscriptional regulation of mRNA targets by miRNAs. $(A)$ Target mRNA translation: interaction between poly(A)-binding protein (PABP) on poly(A) tail with translation initiation factors eIF4G/eIF4E on Cap stimulates translation (Gallie 1991; Kapp and Lorsch 2004). (B) miRNA-induced target mRNA deadenylation: miRISC (Pillai 2005; Valencia-Sanchez et al. 2006) is recruited to the 3'UTR of target mRNA and accelerates deadenylation by a 3'-to-5' exonuclease (Richter 1999; de Moor et al. 2005; Giraldez et al. 2006; Vasudevan et al. 2006; Wu et al. 2006). (C) Loss of target mRNA translation: the interaction between PABP and eIF4G/eIF4E is disrupted, resulting in loss of translation initiation (Gallie 1991; Kapp and Lorsch 2004; Valencia-Sanchez et al. 2006). (D) Target mRNA degradation: Loss of poly(A) tail results in decapping and degradation of target mRNA (Rehwinkel et al. 2005). Steps 3 and 4 are likely to occur in P-bodies (Sheth and Parker 2003; Chen et al. 2005; Ding et al. 2005; Jakymiw et al. 2005; Liu et al. 2005; Pillai 2005; Pillai et al. 2005; Rehwinkel et al. 2005; Sen and Blau 2005). The suggested role for miRNAs in accelerating mRNA deadenylation would disrupt the interaction Cap-poly(A) tail and provide a substrate for exonucleases. This could explain how miRNAs cause translational repression and mRNA decay. (Reprinted, with permission, from Giraldez et al. 2006 [C AAAS].) 
miR-430 seems to revert this process by inducing the deadenylation and decay of maternal mRNAs.

\section{CONCLUSIONS}

The powerful combination of genetics, embryology, molecular biology, and bioinformatics has helped us to clarify the functions and mechanisms of miRNAs during vertebrate embryogenesis. But how general are the lessons learned from miR-430 and zebra fish embryos?

\section{MIRNAS HAVE MODULATORY ROLES}

Lack of miRNAs in MZdicer mutants leads to morphogenesis defects but does not lead to global disruption of fate specification or signaling. Our results therefore suggest that miRNAs have mainly modulatory roles. Indeed, miR-430 is the most abundant, if not the only, miRNA expressed during early zebra fish embryogenesis (Chen et al. 2005; Giraldez et al. 2005; Wienholds et al. 2005). Apparently, miRNAs are employed in a much more restricted fashion than are the dozens of transcription factors that specify embryonic cell fates (Schier and Talbot 2005). Similarly, loss of Dicer activity does not appear to affect zebra fish germ-cell development, suggesting that miRNAs play no or minor roles in the development of some cell types. Moreover, it is conceivable that no or few miRNAs are expressed in germ cells, despite or because of the presence of other small RNAs (Aravin et al. 2006; Girard et al. 2006; Grivna et al. 2006; Lau et al. 2006). Taken together, the results in zebra fish indicate that some cell types do not rely on microRNAs for specification and differentiation.

Studies in other systems partially support this view. For example, conditional ablation of mouse dicer in limbs or skin results in abnormal morphogenesis but does not lead to defects in cell-fate specification (Harfe et al. 2005; Andl et al. 2006; Yi et al. 2006). Similarly, loss of Drosophila miR-1, a muscle-specific miRNA, does not affect cell-fate specification, but morphogenesis during larval stages (Sokol and Ambros 2005). In contrast, studies in Caenorhabditis elegans have emphasized the role of the miRNAs lin-4, let-7, and lsy-6 in cell-fate decisions (Lee et al. 1993; Wightman et al. 1993; Reinhart et al. 2000; Johnston and Hobert 2003) and miR-61 in cell signaling (Yoo and Greenwald 2005). However, it is possible that the $C$. elegans data are skewed, because these miRNAs were identified in specific screens for fate defects. Our results would predict that other C. elegans miRNAs have more subtle roles. Conversely, it will be important to determine whether the many tissue-specific miRNAs expressed at later stages of zebra fish development have roles in fate specification or tissue homeostasis and physiology (Stark et al. 2003, 2005; Xu et al. 2003; Poy et al. 2004; Boehm and Slack 2005; Farh et al. 2005; Krutzfeldt et al. 2005; Lim et al. 2005; Wienholds et al. 2005; Hornstein and Shomron 2006; Kloosterman and Plasterk 2006; Kloosterman et al. 2006; Sood et al. 2006; Teleman et al. 2006). Ultimately, it is likely that miRNAs will be found to have a wide range of functions, but it is striking that current evidence points to modulatory or highly redundant roles.

\section{MIRNAS FACILITATE DEVELOPMENTAL TRANSITIONS}

miR-430 facilitates the maternal-to-zygotic transition. Importantly, this transition is not blocked in the absence of miR-430, and the embryo does not arrest in the maternal state. Rather, the zygotic state is initiated, but mRNAs from the maternal phase are not cleared efficiently and thus interfere with subsequent development. These observations led us to suggest that miRNAs might not serve as developmental switches, but simply remove mRNAs from previous developmental states. This "spring cleaning" function ensures proper transitions from states A to $\mathrm{B}$ to $\mathrm{C}$, and thus avoids the formation of mixed states $\mathrm{B} / \mathrm{C}$ (Fig. 8). This model contrasts with C. elegans studies which have shown that loss of lin-4 and let-7 leads to heterochronic phenotypes, in which the animal reiterates earlier cell-fate decisions instead of initiating the next developmental stage (Ambros 1989; Lee et al. 1993; Wightman et al. 1993; Reinhart et al. 2000; AlvarezGarcia and Miska 2005). Instead of transitioning from A to $\mathrm{B}$ to $\mathrm{C}$, certain lineages repeat the $\mathrm{A}$ to $\mathrm{B}$ transition and do not enter C. Despite these apparent differences, miR430 , lin-4, and let-7 all act during developmental transitions, and it is possible that a specific phenotypic defect depends on the nature of the targets and the developmental context. For example, the accumulation of some targets might block the transition to the next stage, but in other systems the loss of the miRNA might cause a mixed state or delay the transition to a new state.

The role of miRNAs in developmental transitions has important implications for miRNA misregulation. For example, premature expression of a miRNA could preemptively block genes expressed at a later stage and thus
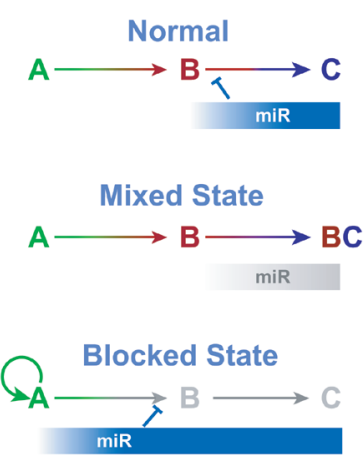

Figure 8. Model of miRNA function during development. Cell transitions from state A to state B to state C. Normal: miRNA is activated at the B-to- $\mathrm{C}$ transition and posttranscriptionally regulates mRNAs expressed in state $\mathrm{B}$, thus sharpening and accelerating the transition from state B to state C (Rhoades et al. 2002; Giraldez et al. 2006). Mixed State: In the absence of the miRNA, gene products from state B accumulate, leading to a mixed state B/C. Blocked State: In disease states or upon experimental misexpression, the miRNA is expressed prematurely, resulting in the posttranscriptional regulation of genes normally expressed in state $\mathrm{B}$. This prevents the transition from state A to state B, leading to the maintenance of state A. In the case of cancer, state A might correspond to a cancer stem cell (Beachy et al. 2004; He et al. 2005; Lu et al. 2005; Dalerba et al. 2006; Dews et al. 2006; Voorhoeve et al. 2006). (Reprinted, with permission, from Giraldez et al. 2006 [C AAAS].) 
prevent developmental transitions (Fig. 8). This mechanism might explain how some miRNAs can function as oncogenes (He et al. 2005; Lu et al. 2005; Dews et al. 2006; Voorhoeve et al. 2006).

MiR-430 continues to be expressed during the first two days of zebra fish embryogenesis, and many of its targets are expressed during these stages (Giraldez et al. 2006). It is therefore likely that miR-430 does not only function in the maternal-to-zygotic transition, but also dampens the expression of zygotically expressed genes. Such a homeostatic role resembles the proposed roles of miRNAs in maintenance of tissue states or metabolic states (Stark et al. 2003, 2005; Xu et al. 2003; Poy et al. 2004; Boehm and Slack 2005; Farh et al. 2005; Krutzfeldt et al. 2005; Lim et al. 2005; Hornstein and Shomron 2006; Sood et al. 2006; Teleman et al. 2006).

\section{MIRNAS HAVE HUNDREDS OF IN VIVO TARGETS}

miR-430 regulates hundreds of mRNAs. These in vivo observations support cell culture and bioinformatics studies which have suggested that miRNAs have dozens of targets (Enright et al. 2003; Stark et al. 2003, 2005; Kiriakidou et al. 2004; Poy et al. 2004; Rehmsmeier et al. 2004; Krek et al. 2005; Lewis et al. 2005; Lall et al. 2006; Miranda et al. 2006). In contrast, genetic studies in C. elegans have identified a few key targets whose up-regulation leads to the phenotypes caused by loss of specific miRNAs (Lee et al. 1993; Wightman et al. 1993; Reinhart et al. 2000; Slack et al. 2000; Abrahante et al. 2003; Johnston and Hobert 2003; Lin et al. 2003; Abbott et al. 2005; Boehm and Slack 2005; Grosshans et al. 2005; Johnson et al. 2005; Yoo and Greenwald 2005). These two observations are not necessarily contradictory. It is conceivable that miRNAs have the capacity to regulate hundreds of targets but that the upregulation of only a small subset of targets has severe phenotypic consequences. Detailed functional analysis of target genes is necessary to determine which and how many targets contribute to a given phenotype.

\section{SOME MIRNA TARGETS ARE DIFFERENTIALLY REGULATED}

Most miR-430 targets are uniformly susceptible to repression, but a small subset appears to be partially protected in germ cells. It is therefore conceivable that many mRNAs have acquired specific sequences that counteract the effect of miRNAs in specific tissues, times, or cell states. For example, nanos and tudor-like are miR-430 targets in somatic cells but are translated in germ cells (Mishima et al. 2006), and in tissue culture, repression of cat-1 by miR-122 is relieved upon cellular stress (Bhattacharyya et al. 2006). Such "antagonistic targets" complement "anti-targets," which have evolved to lack miRNA-binding sites (Bartel and Chen 2004; Farh et al. 2005; Stark et al. 2005; Sood et al. 2006). Hence, mRNAs can avoid miRNA regulation by either lacking a miRNAbinding site (anti-targets) or by evolving sites that counteract the miRNA's effects (antagonistic targets). The advantage of the latter strategy is that target repression can be regulated in a tissue-, stage-, or state-specific manner. It remains to be seen how common this mechanism is, but it might account for the observation that many predicted miRNA targets do not seem to be regulated by a given miRNA (Lewis et al. 2003; Stark et al. 2003, 2005; Giraldez et al. 2006; Miranda et al. 2006). These results also highlight the importance of in vivo validation of putative targets by testing the role of their full-length 3'UTRs.

\section{MIRNAS REGULATE TARGET MRNAS BY DEADENYLATION}

miR-430 accelerates the deadenylation of mRNA targets (Giraldez et al. 2006; Mishima et al. 2006). Further support for a role for miRNAs in deadenylation has come from cell culture studies (Wu et al. 2006) and the identification of deadenylases involved in miRNA target degradation (Behm-Ansmant et al. 2006). In some cases, however, miRNAs seem to be able to repress translation in the absence of deadenylation (Humphreys et al. 2005; $\mathrm{Wu}$ et al. 2006) or mRNA degradation (Pillai 2005; Petersen et al. 2006). It is therefore possible that deadenylation is one of several mechanisms that contribute to target regulation. However, since deadenylation ultimately leads to both translational repression and mRNA decay, the two main effects of miRNA action, it is tempting to speculate that deadenylation is the trigger for miRNA-mediated repression.

\section{ACKNOWLEDGMENTS}

We thank our colleagues and collaborators for their essential contributions, and Kevin Eggan and Susan Mango for helpful comments on the manuscript. A.J.G. was supported by EMBO and is currently supported by a Human Frontier Science Program fellowship. A.F.S. was an Irma T. Hirschl Trust Career Scientist and an Established Investigator of the American Heart Association. This work was also supported by grants from the National Institutes of Health (A.F.S).

\section{REFERENCES}

Abbott A.L., Alvarez-Saavedra E., Miska E.A., Lau N.C., Bartel D.P., Horvitz H.R., and Ambros V. 2005. The let-7 MicroRNA family members mir-48 mir-84 and mir-241 function together to regulate developmental timing in Caenorhabditis elegans. Dev. Cell. 9: 403.

Abrahante J.E., Daul A.L., Li M., Volk M.L., Tennessen J.M., Miller E.A., and Rougvie A.E. 2003. The Caenorhabditis elegans hunchback-like gene lin-57/hbl-1 controls developmental time and is regulated by microRNAs. Dev. Cell. 4: 625.

Alvarez-Garcia I. and Miska E.A. 2005. MicroRNA functions in animal development and human disease. Development 132: 4653.

Ambros V. 1989. A hierarchy of regulatory genes controls a larva-to-adult developmental switch in C. elegans. Cell 57: 49.

. 2004. The functions of animal microRNAs. Nature 431: 350 .

Andl T., Murchison E.P., Liu F., Zhang Y., Yunta-Gonzalez M., Tobias J.W., Andl C.D., Seykora J.T., Hannon G.J., and Millar S.E. 2006. The miRNA-processing enzyme dicer is essential for the morphogenesis and maintenance of hair follicles. Curr. Biol. 16: 1041. 
Aravin A., Gaidatzis D., Pfeffer S., Lagos-Quintana M., Landgraf P., Iovino N., Morris P., Brownstein M.J., Kuramochi-Miyagawa S., Nakano T., et al. 2006. A novel class of small RNAs bind to MILI protein in mouse testes. Nature 442: 203.

Bagga S., Bracht J., Hunter S., Massirer K., Holtz J., Eachus R., and Pasquinelli A.E. 2005. Regulation by let-7 and lin-4 miRNAs results in target mRNA degradation. Cell 122: 553.

Bartel D.P. 2004. MicroRNAs: Genomics, biogenesis, mechanism, and function. Cell 116: 281.

Bartel D.P. and Chen C.Z. 2004. Micromanagers of gene expression: The potentially widespread influence of metazoan microRNAs. Nat. Rev. Genet. 5: 396.

Beachy P.A., Karhadkar S.S., and Berman D.M. 2004. Tissue repair and stem cell renewal in carcinogenesis. Nature 432: 324.

Behm-Ansmant I., Rehwinkel J., Doerks T., Stark A., Bork P., and Izaurralde E. 2006. mRNA degradation by miRNAs and GW182 requires both CCR4:NOT deadenylase and DCP1:DCP2 decapping complexes. Genes Dev. 20: 1885.

Bentwich I., Avniel A., Karov Y., Aharonov R., Gilad S., Barad O., Barzilai A., Einat P., Einav U., Meiri E., et al. 2005. Identification of hundreds of conserved and nonconserved human microRNAs. Nat. Genet. 37: 766.

Berezikov E., Guryev V., van de Belt J., Wienholds E., Plasterk R.H., and Cuppen E. 2005. Phylogenetic shadowing and computational identification of human microRNA genes. Cell 120: 21 .

Bernstein E., Caudy A.A., Hammond S.M., and Hannon G.J. 2001. Role for a bidentate ribonuclease in the initiation step of RNA interference. Nature 409: 363.

Bhattacharyya S.N., Habermacher R., Martine U., Closs E.I., and Filipowicz W. 2006. Relief of microRNA-mediated translational repression in human cells subjected to stress. Cell 125: 1111.

Boehm M. and Slack F. 2005. A developmental timing microRNA and its target regulate life span in C. elegans. Science 310: 1954.

Brennecke J., Stark A., Russell R.B., and Cohen S.M. 2005. Principles of microRNA-target recognition. PLoS Biol. 3: e85.

Chen P.Y., Manninga H., Slanchev K., Chien M., Russo J.J., Ju J., Sheridan R., John B., Marks D.S., Gaidatzis D., et al. 2005. The developmental miRNA profiles of zebra fish as determined by small RNA cloning. Genes Dev. 19: 1288

Ciruna B., Weidinger G., Knaut H., Thisse B., Thisse C., Raz E., and Schier A.F. 2002. Production of maternal-zygotic mutant zebra fish by germ-line replacement. Proc. Natl. Acad. Sci. 99: 14919.

Dalerba P., Cho R.W., and Clarke M.F. 2006. Cancer stem cells: Models and concepts. Annu. Rev. Med. (in press).

de Moor C.H., Meijer H., and Lissenden S. 2005. Mechanisms of translational control by the 3'UTR in development and differentiation. Semin. Cell Dev. Biol. 16: 49.

Dews M., Homayouni A., Yu D., Murphy D., Sevignani C., Wentzel E., Furth E.E., Lee W.M., Enders G.H., Mendell J.T., and Thomas-Tikhonenko A. 2006. Augmentation of tumor angiogenesis by a Myc-activated microRNA cluster. Nat. Genet. 38: 1060

Ding L., Spencer A., Morita K., and Han M. 2005. The developmental timing regulator AIN-1 interacts with miRISCs and may target the argonaute protein ALG-1 to cytoplasmic P bodies in C. elegans. Mol. Cell 19: 437.

Doench J.G. and Sharp P.A. 2004. Specificity of microRNA target selection in translational repression. Genes Dev. 18: 504.

Enright A.J., John B., Gaul U., Tuschl T., Sander C., and Marks D.S. 2003. MicroRNA targets in Drosophila. Genome Biol. 5: R1.

Farh K.K., Grimson A., Jan C., Lewis B.P., Johnston W.K., Lim L.P., Burge C.B., and Bartel D.P. 2005. The widespread impact of mammalian MicroRNAs on mRNA repression and evolution. Science 310: 1817.

Gallie D.R. 1991. The cap and poly(A) tail function synergistically to regulate mRNA translational efficiency. Genes Dev. 5: 2108 .
Giraldez A.J., Mishima Y., Rihel J., Grocock R.J., Van Dongen S., Inoue K., Enright A.J., and Schier A.F. 2006. Zebra fish MiR-430 promotes deadenylation and clearance of maternal mRNAs. Science 312: 75

Giraldez A.J., Cinalli R.M., Glasner M.E., Enright A.J., Thomson J.M., Baskerville S., Hammond S.M., Bartel D.P., and Schier A.F. 2005. MicroRNAs regulate brain morphogenesis in zebra fish. Science 308: 833 .

Girard A., Sachidanandam R., Hannon G.J., and Carmell M.A. 2006. A germline-specific class of small RNAs binds mammalian Piwi proteins. Nature 442: 199.

Grishok A., Pasquinelli A.E., Conte D., Li N., Parrish S., Ha I., Baillie D.L., Fire A., Ruvkun G., and Mello C.C. 2001. Genes and mechanisms related to RNA interference regulate expression of the small temporal RNAs that control C. elegans developmental timing. Cell 106: 23.

Grivna S.T., Beyret E., Wang Z., and Lin H. 2006. A novel class of small RNAs in mouse spermatogenic cells. Genes Dev. 20: 1709.

Grosshans H., Johnson T., Reinert K.L., Gerstein M., and Slack F.J. 2005. The temporal patterning microRNA let-7 regulates several transcription factors at the larval to adult transition in C. elegans. Dev. Cell 8: 321 .

Hammond S.M., Bernstein E., Beach D., and Hannon G.J. 2000. An RNA-directed nuclease mediates post-transcriptional gene silencing in Drosophila cells. Nature 404: 293.

Harfe B.D., McManus M.T., Mansfield J.H., Hornstein E., and Tabin C.J. 2005. The RNaseIII enzyme Dicer is required for morphogenesis but not patterning of the vertebrate limb. Proc. Natl. Acad. Sci. 102: 10898.

He L., Thomson J.M., Hemann M.T., Hernando-Monge E., Mu D., Goodson S., Powers S., Cordon-Cardo C., Lowe S.W., Hannon G.J., and Hammond S.M. 2005. A microRNA polycistron as a potential human oncogene. Nature 435: 828 .

Hornstein E. and Shomron N. 2006. Canalization of development by microRNAs. Nat. Genet. (suppl.) 38: S20.

Humphreys D.T., Westman B.J., Martin D.I., and Preiss T. 2005. MicroRNAs control translation initiation by inhibiting eukaryotic initiation factor 4E/cap and poly(A) tail function. Proc. Natl. Acad. Sci. 102: 16961.

Hutvagner G. and Zamore P.D. 2002. A microRNA in a multiple-turnover RNAi enzyme complex. Science 297: 2056.

Hutvagner G., McLachlan J., Pasquinelli A.E., Balint E., Tuschl T., and Zamore P.D. 2001. A cellular function for the RNAinterference enzyme Dicer in the maturation of the let-7 small temporal RNA. Science 293: 834.

Jakymiw A., Lian S., Eystathioy T., Li S., Satoh M., Hamel J.C., Fritzler M.J., and Chan E.K. 2005. Disruption of GW bodies impairs mammalian RNA interference. Nat. Cell. Biol. 7: 1267.

Johnson S.M., Grosshans H., Shingara J., Byrom M., Jarvis R., Cheng A., Labourier E., Reinert K.L., Brown D., and Slack F.J. 2005. RAS is regulated by the let-7 microRNA family. Cell 120: 635.

Johnston R.J. and Hobert O. 2003. A microRNA controlling left/right neuronal asymmetry in Caenorhabditis elegans. Nature 426: 845 .

Kane D.A. and Kimmel C.B. 1993. The zebra fish midblastula transition. Development 119: 447.

Kapp L.D. and Lorsch J.R. 2004. The molecular mechanics of eukaryotic translation. Annu. Rev. Biochem. 73: 657.

Ketting R.F., Fischer S.E., Bernstein E., Sijen T., Hannon G.J., and Plasterk R.H. 2001. Dicer functions in RNA interference and in synthesis of small RNA involved in developmental timing in C. elegans. Genes Dev. 15: 2654.

Khvorova A., Reynolds A., and Jayasena S.D. 2003. Functional siRNAs and miRNAs exhibit strand bias. Cell 115: 209.

Kiriakidou M., Nelson P.T., Kouranov A., Fitziev P., Bouyioukos C., Mourelatos Z., and Hatzigeorgiou A. 2004. A combined computational-experimental approach predicts human microRNA targets. Genes Dev. 18: 1165.

Kloosterman W.P. and Plasterk R.H. 2006. The diverse functions of microRNAs in animal development and disease. Dev. Cell 11: 441 . 
Kloosterman W.P., Steiner F.A., Berezikov E., de Bruijn E., van de Belt J., Verheul M., Cuppen E., and Plasterk R.H. 2006. Cloning and expression of new microRNAs from zebra fish. Nucleic Acids Res. 34: 2558.

Knaut H., Pelegri F., Bohmann K., Schwarz H., and NüssleinVolhard C. 2000. Zebra fish vasa RNA but not its protein is a component of the germ plasm and segregates asymmetrically before germline specification. J. Cell Biol. 149: 875 .

Knight S.W. and Bass B.L. 2001. A role for the RNase III enzyme DCR-1 in RNA interference and germ line development in Caenorhabditis elegans. Science 293: 2269.

Koprunner M., Thisse C., Thisse B., and Raz E. 2001. A zebra fish nanos-related gene is essential for the development of primordial germ cells. Genes Dev. 15: 2877.

Krek A., Grun D., Poy M.N., Wolf R., Rosenberg L., Epstein E.J., MacMenamin P., da Piedade I., Gunsalus K.C., Stoffel M., and Rajewsky N. 2005. Combinatorial microRNA target predictions. Nat. Genet. 37: 495.

Krutzfeldt J., Rajewsky N., Braich R., Rajeev K.G., Tuschl T., Manoharan M., and Stoffel M. 2005. Silencing of microRNAs in vivo with 'antagomirs'. Nature 438: 685.

Lagos-Quintana M., Rauhut R., Lendeckel W., and Tuschl T. 2001. Identification of novel genes coding for small expressed RNAs. Science 294: 853.

Lai E.C. 2002. Micro RNAs are complementary to 3'UTR sequence motifs that mediate negative post-transcriptional regulation. Nat. Genet. 30: 363.

. 2005. miRNAs: Whys and wherefores of miRNA-mediated regulation. Curr. Biol. 15: R458.

Lall S., Grun D., Krek A., Chen K., Wang Y.L., Dewey C.N., Sood P., Colombo T., Bray N., Macmenamin P., et al. 2006. A genome-wide map of conserved microRNA targets in $C$. elegans. Curr. Biol. 16: 460.

Lau N.C., Lim L.P., Weinstein E.G., and Bartel D.P. 2001. An abundant class of tiny RNAs with probable regulatory roles in Caenorhabditis elegans. Science 294: 858.

Lau N.C., Seto A.G., Kim J., Kuramochi-Miyagawa S., Nakano T., Bartel D.P., and Kingston R.E. 2006. Characterization of the piRNA complex from rat testes. Science 313: 363.

Lee R.C. and Ambros V. 2001. An extensive class of small RNAs in Caenorhabditis elegans. Science 294: 862.

Lee R.C., Feinbaum R.L., and Ambros V. 1993. The C. elegans heterochronic gene lin-4 encodes small RNAs with antisense complementarity to lin-14. Cell 75: 843 .

Lewis B.P., Burge C.B., and Bartel D.P. 2005. Conserved seed pairing often flanked by adenosines indicates that thousands of human genes are microRNA targets. Cell 120: 15.

Lewis B.P., Shih I.H., Jones-Rhoades M.W., Bartel D.P., and Burge C.B. 2003. Prediction of mammalian microRNA targets. Cell 115: 787.

Lim L.P., Lau N.C., Garrett-Engele P., Grimson A., Schelter J.M., Castle J., Bartel D.P., Linsley P.S., and Johnson J.M. 2005. Microarray analysis shows that some microRNAs downregulate large numbers of target mRNAs. Nature 433: 769.

Lin S.Y., Johnson S.M., Abraham M., Vella M.C., Pasquinelli A., Gamberi C., Gottlieb E., and Slack F.J. 2003. The C. elegans hunchback homolog hbl-1 controls temporal patterning and is a probable microRNA target. Dev. Cell. 4: 639.

Liu J., Valencia-Sanchez M.A., Hannon G.J., and Parker R. 2005. MicroRNA-dependent localization of targeted mRNAs to mammalian P-bodies. Nat. Cell Biol. 7: 719.

Lu J., Getz G., Miska E.A., Alvarez-Saavedra E., Lamb J., Peck D., Sweet-Cordero A., Ebert B.L., Mak R.H., Ferrando A.A., et al. 2005. MicroRNA expression profiles classify human cancers. Nature 435: 834.

McGrew L.L., Dworkin-Rastl E., Dworkin M.B., and Richter J.D. 1989. Poly(A) elongation during Xenopus oocyte maturation is required for translational recruitment and is mediated by a short sequence element. Genes Dev. 3: 803.

Miranda K.C., Huynh T., Tay Y., Ang Y.S., Tam W.L., Thomson A.M., Lim B., and Rigoutsos I. 2006. A patternbased method for the identification of MicroRNA binding sites and their corresponding heteroduplexes. Cell 126: 1203.
Mishima Y., Giraldez A.J., Takeda Y., Fujiwara T., Sakamoto H., Schier A.F., and Inoue K. 2006. Differential regulation of germline mRNAs in soma and germ cells by zebra fish miR430. Curr. Biol. 16: 2135.

Newport J. and Kirschner M. 1982a. A major developmental transition in early Xenopus embryos. I. Characterization and timing of cellular changes at the midblastula stage. Cell 30: 675 .

1982b. A major developmental transition in early Xenopus embryos. II. Control of the onset of transcription. Cell 30: 687.

Olsen P.H. and Ambros V. 1999. The lin-4 regulatory RNA controls developmental timing in Caenorhabditis elegans by blocking LIN-14 protein synthesis after the initiation of translation. Dev. Biol. 216: 671.

Ota A., Tagawa H., Karnan S., Tsuzuki S., Karpas A., Kira S., Yoshida Y., and Seto M. 2004. Identification and characterization of a novel gene C13orf25 as a target for 13q31-q32 amplification in malignant lymphoma. Cancer Res. 64: 3087.

Pelegri F. 2003. Maternal factors in zebra fish development. Dev. Dyn. 228: 535.

Petersen C.P., Bordeleau M.E., Pelletier J., and Sharp P.A. 2006. Short RNAs repress translation after initiation in mammalian cells. Mol. Cell 21: 533.

Pillai R.S. 2005. MicroRNA function: Multiple mechanisms for a tiny RNA? RNA 11: 1753.

Pillai R.S., Bhattacharyya S.N., Artus C.G., Zoller T., Cougot N., Basyuk E., Bertrand E., and Filipowicz W. 2005. Inhibition of translational initiation by Let-7 MicroRNA in human cells. Science 309: 1573.

Poy M.N., Eliasson L., Krutzfeldt J., Kuwajima S., Ma X., Macdonald P.E., Pfeffer S., Tuschl T., Rajewsky N., Rorsman P., and Stoffel M. 2004. A pancreatic islet-specific microRNA regulates insulin secretion. Nature 432: 226.

Rajewsky N. 2006. microRNA target predictions in animals. Nat. Genet. (suppl.) 38: S8.

Raz E. 2004. Guidance of primordial germ cell migration. Curr. Opin. Cell Biol. 16: 169

Rehmsmeier M., Steffen P., Hochsmann M., and Giegerich R. 2004. Fast and effective prediction of microRNA/target duplexes. RNA 10: 1507.

Rehwinkel J., Behm-Ansmant I., Gatfield D., and Izaurralde E. 2005. A crucial role for GW182 and the DCP1:DCP2 decapping complex in miRNA-mediated gene silencing. RNA 11: 1640.

Reinhart B.J., Slack F.J., Basson M., Pasquinelli A.E., Bettinger J.C., Rougvie A.E., Horvitz H.R., and Ruvkun G. 2000. The 21-nucleotide let-7 RNA regulates developmental timing in Caenorhabditis elegans. Nature 403: 901.

Rhoades M.W., Reinhart B.J., Lim L.P., Burge C.B., Bartel B., and Bartel D.P. 2002. Prediction of plant microRNA targets. Cell 110: 513.

Richter J.D. 1999. Cytoplasmic polyadenylation in development and beyond. Microbiol. Mol. Biol. Rev. 63: 446.

Richter J.D., Paris J., and McGrew L.L. 1990. Maternal mRNA expression in early development: Regulation at the $3^{\prime}$ end. Enzyme 44: 129.

Schier A.F. and Talbot W.S. 2005. Molecular genetics of axis formation in zebra fish. Annu. Rev. Genet. 39: 561.

Schwarz D.S., Hutvagner G., Du T., Xu Z., Aronin N., and Zamore P.D. 2003. Asymmetry in the assembly of the RNAi enzyme complex. Cell 115: 199.

Sen G.L. and Blau H.M. 2005. Argonaute 2/RISC resides in sites of mammalian mRNA decay known as cytoplasmic bodies. Nat. Cell Biol. 7: 633.

Sheth U. and Parker R. 2003. Decapping and decay of messenger RNA occur in cytoplasmic processing bodies. Science 300: 805 .

Slack F.J., Basson M., Liu Z., Ambros V., Horvitz H.R., and Ruvkun G. 2000. The lin-41 RBCC gene acts in the C. elegans heterochronic pathway between the let-7 regulatory RNA and the LIN-29 transcription factor. Mol. Cell 5: 659.

Slater D.W., Slater I., and Gillespie D. 1972. Post-fertilization synthesis of polyadenylic acid in sea urchin embryos. Nature 240: 333 . 
Slater I., Gillespie D., and Slater D.W. 1973. Cytoplasmic adenylylation and processing of maternal RNA. Proc. Natl. Acad. Sci. 70: 406.

Sokol N.S. and Ambros V. 2005. Mesodermally expressed Drosophila microRNA-1 is regulated by Twist and is required in muscles during larval growth. Genes Dev. 19: 2343.

Sood P., Krek A., Zavolan M., Macino G., and Rajewsky N. 2006. Cell-type-specific signatures of microRNAs on target mRNA expression. Proc. Natl. Acad. Sci. 103: 2746.

Stark A., Brennecke J., Russell R.B., and Cohen S.M. 2003. Identification of Drosophila MicroRNA targets. PLoS Biol. 1: E60.

Stark A., Brennecke J., Bushati N., Russell R.B., and Cohen S.M. 2005. Animal MicroRNAs confer robustness to gene expression and have a significant impact on 3'UTR evolution. Cell 123: 1133.

Teleman A.A., Maitra S., and Cohen S.M. 2006. Drosophila lacking microRNA miR-278 are defective in energy homeostasis. Genes Dev. 20: 417.

Valencia-Sanchez M.A., Liu J., Hannon G.J., and Parker R. 2006. Control of translation and mRNA degradation by miRNAs and siRNAs. Genes Dev. 20: 515.

Vasudevan S., Seli E., and Steitz J.A. 2006. Metazoan oocyte and early embryo development program: A progression through translation regulatory cascades. Genes Dev. 20: 138.

Voorhoeve P.M., le Sage C., Schrier M., Gillis A.J., Stoop H., Nagel R., Liu Y.P., van Duijse J., Drost J., Griekspoor A., et al. 2006. A genetic screen implicates miRNA-372 and miRNA-373 as oncogenes in testicular germ cell tumors. Cell 124: 1169 .
Watanabe T., Takeda A., Mise K., Okuno T., Suzuki T., Minami N., and Imai H. 2005. Stage-specific expression of microRNAs during Xenopus development. FEBS Lett. 579: 318.

Wienholds E., Kloosterman W.P., Miska E., Alvarez-Saavedra E., Berezikov E., de Bruijn E., Horvitz H.R., Kauppinen S., and Plasterk R.H. 2005. MicroRNA expression in zebra fish embryonic development. Science 309: 310.

Wightman B., Ha I., and Ruvkun G. 1993. Posttranscriptional regulation of the heterochronic gene lin-14 by lin- 4 mediates temporal pattern formation in C. elegans. Cell 75: 855.

Wilt F.H. 1973. Polyadenylation of maternal RNA of sea urchin eggs after fertilization. Proc. Natl. Acad. Sci. 70: 2345.

Wu L., Fan J., and Belasco J.G. 2006. MicroRNAs direct rapid deadenylation of mRNA. Proc. Natl. Acad. Sci. 103: 4034.

Xu P., Vernooy S.Y., Guo M., and Hay B.A. 2003. The Drosophila microRNA Mir-14 suppresses cell death and is required for normal fat metabolism. Curr. Biol. 13: 790.

Yi R., O'Carroll D., Pasolli H.A., Zhang Z., Dietrich F.S., Tarakhovsky A., and Fuchs E. 2006. Morphogenesis in skin is governed by discrete sets of differentially expressed microRNAs. Nat. Genet. 38: 356.

Yoo A.S. and Greenwald I. 2005. LIN-12/Notch activation leads to microRNA-mediated down-regulation of Vav in C. elegans. Science 310: 1330.

Yoon C., Kawakami K., and Hopkins N. 1997. Zebra fish vasa homologue RNA is localized to the cleavage planes of 2- and 4-cell-stage embryos and is expressed in the primordial germ cells. Development 124: 3157. 


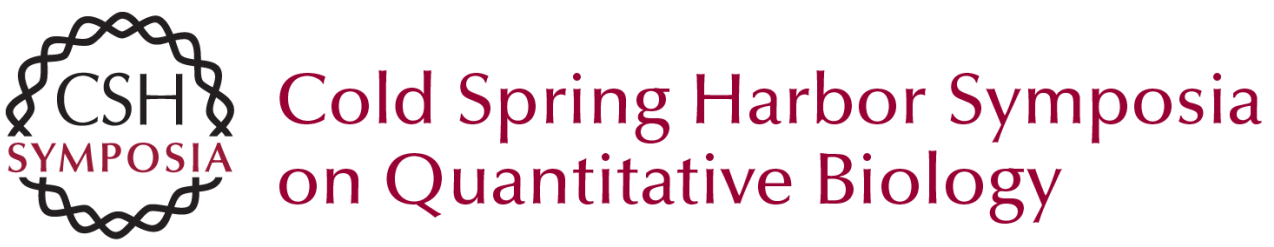

\section{MicroRNA Function and Mechanism: Insights from Zebra Fish}

A.F. SCHIER and A.J. GIRALDEZ

Cold Spring Harb Symp Quant Biol 2006 71: 195-203

Access the most recent version at doi:10.1101/sqb.2006.71.055

References This article cites 113 articles, 44 of which can be accessed free at: http://symposium.cshlp.org/content/71/195.full.html\#ref-list-1

License

Email Alerting Receive free email alerts when new articles cite this article - sign up in Service the box at the top right corner of the article or click here. 